\title{
THE UTILIZATION OF FOLKLORES AND THE HAPPY STRATEGY TO IMPROVE ENGLISH SPEAKING SKILL AND SELF CONCEPT (BEST PRACTICES FOR NONFORMAL EDUCATION)
}

\author{
Wiwiek Afifah \\ STPI Bina Insan Mulia Yogyakarta, Indonesia \\ afifah.ardi@gmail.com
}

\begin{abstract}
This paper aims to discuss: (1) the integration of moral values through folklore in narrative texts, (2) the implementation of the happy strategy in teaching and learning processes, and (3) the improvement of speaking skill and self concept.

The integration of moral values in folklores as narrative texts can be done to fulfil the learning targets. It is because students will be supported to internalize and actualize those values in their life. Some moral values that can be stressed in the integration of folklores are how to be an honest one, confident, careful, communicative, and down to earth person. The Happy strategies are joyful learning activities that can support students in learning how to speak effectively. It is because learning experiences on how to speak and to communicate were framed fun and relax. The characteristic of the happy strategies included ice breaking, storytelling, role playing, self assessment, peer assessment, and selected report. The strategy also made students felt directly aware of their performance from the result of peer assessment.

The teaching strategy that had been implemented in non formal education especially for packet B program was proven to be appropriated. Having been implemented the language input (moral values based on folklores) and the happy strategies, student's linguistic competence, linguistics performance (speaking skill) were improved. Furthermore, student's self concept also changed to be better. It is because they can learn some moral values from the folklores and strengthen them through the reflection session of the class.
\end{abstract}

Keywords: folklore, happy strategy, speaking skill, and self concept

\section{INTRODUCTION}

Teaching English in the centre of society learning activities as a part of non formal education is for helping and facilitating students to use English in their daily life. The students are expected to have functional skills and abilities to overcome their own problems using the competencies possesed by them. As stated in the curriculum, one of the basic competencies to be achieved at these levels is that they should be able to express meaning in a simple short monologue text so they can interact with people around them using the target language they learnt.

However, in fact, a number of problems dealing with students' problems had been found. The students in the centre of society learning activities in particularly packet B program still found difficulties to master those basic competences including; (a) linguistics competences, (b) linguistics performance, and (c) moral values. These three problems appeared in the class emerged some crucial fidgetiness for example; (1) a low academic achievement, (2) feeling inferior, and (3) pessimistic. The low academic achievement was proven by the students' result which was only $10 \%$ of them enabling to achieve the target of minimum criteria. The feelings inferior and pessimistic were observably when some challenging tasks were given to them. They directly ignored and showed a low interest on doing the task. 
Moreover, students felt indifferent to their capability. Although they were aware of their level competenceies, they did not have a good efford to improve them. Most of the students recognized that learning English was difficult thus they felt inferior to improve it. Indeed, there are a number of facts that indicated students did not have a positive of self concept. A positive actual self, ideal self, and ought self toward their future with English skill did not turn up yet.

In English language teaching and learning, a narrative text is one of the texts that must be mastered by the students. The narrative texts can be in the form of folklore, legend, fable and the others in which their general purposes are to entertain, to amuse, and to provide educational values to their readers. After studying narrative texts, students are expected to be able to understand the purpose of the texts, the elements that build the story, and the characteristics of language features used in the text.

However, the classroom condition when learning experiences happened especially when the tutor explained narrative texts, the learning classroom atmosphere was not condussive. Moreover, the conditions were increasingly getting worse when the tutor tried to give some questions to the students in English. The classroom became quiet since the communication was not working. When the tutor tried to do a guided conversation, students were also silent even though some of them seemed reluctant to express what they had though.

Based on the students' recognition, when the tutor invited them to practice speaking English, they felt ashamed. It was due to the fact that they found some difficulties in expressing their ideas. They recognized that narrative texts were not easy to understand and to master. By the time the tutor explained the teaching material, students claimed that they understood yet when they were given time to speak, then they surrendered.

Students in non formal education (Packet B Program) admitted that narrative texts were still difficult to master. Since they still found any troubles in understanding the messagae of the text thus it was automatically hard for them to naturally reexpressing the story into spoken texts. Those because of some reasons;

(1) stories taken from textbooks used difficult vocabuaries, (2) stories were strange, and (3) stories were not interesting. Those three causes made them found that learning English were not fun. Moreover, narrative texts were increasing complexity when the students had low self concept.

Responding to the explained problems faced by the author as the tutor in the non formal education for packet B program, this paper aims to discuss some points: (1) the integration of moral values through folklore in narrative texts, (2) the implementation of thehappy strategy in the teaching and learning process, and (3) the improvement of speaking skill and self concept.

\section{LITERATURE REVIEW}

2.1 Speaking Skill

As part of productive skill, speaking functions as the natural means of communication between members of community. Speaking is an important part of everyday interaction and most often the first impression of a person is based on his/her ability to speak fluently and comprehensibly (Liao, 2019: 11) 
As an addition, Richards and Renandya (2002) as cited by Widiati \& Cahyono (2006: 201) stated that "a large percentage of the world language learners study English in order to develop proficiency in speaking". Moreover, Riggenback \& Lazaraton (1991) as also cited by Widiati \& Cahyono (2006: 269) claimed that "students of second/foreign language education programme considered successful if they can communicate effectively in the language".

Speaking is the primary aim of language learning. It is due to the fact that oral communication became the basis of grading the language teaching programs (Richards \& Rodgers, 1986:10) as cited by Widiati \& Cahyono (2006: 270). Along with the belief that speaking is the primary tool for communication, Nation \& Newton (2009: 19-20) axplained there are five principles for teaching English to the students; (1)Meaning Focus on meaningful and relevant language, (2) Interest Maintain interest through a variety of activities, (3) New language Avoid overloading learners with toomuch new language, (4) Understanding Provide plenty of comprehensible input, (5) Stress-free Create a friendly, safe, cooperativeclassroom environment.

Those five principles then are concised into MINUS. Along with the implementation of the five principles to teach English, however there are some points that need to be considered. They are (1) setting the classroom to become much more variety, (2) giving spaces to be used to move, (3) providing a physical comfort, (4) keep building the frequent interaction, (5) showing some successful language experiences, and (6) supporting some opportunities for students to experiment and to make mistakes without penalties.

\subsection{Self-Concept}

Self concept is "individual knowledge and beliefs about themselves; their ideas, feeling, attitudes, and expectation" (Pajares \& Schunk, 2001) via(Woolfolk, 2007: 85). Self concept is a cognitive structure, a believe about oneself, such the believe about one's ability. It means the ability to explain to ourselve about building scheme in which organizing our impression, feeling and beliefs anout ourselves. What is to become structure of self concept is that 'a students' overall self-concept is made up of other more specific concepts including nonacademis self-cconcept about. Such as social relationship, or phisical appearance, and academic self concept in English, Mathematics, and other subject. Those conceptions are built based on the many experiences and events such any kind of evets that happened around their life.

Self concept can develop through constant self evaluation in differences situation. Students will continually using and questioning theirself such as "How am I doing?" Even, students will find their development of self concept through their own improvement over time (Woolfolk, 2007: 85).

2.3 Folklore in English Language Teaching

Hamam (2012) as cited by Kaltsum \& Utami (2016: 24) stated that "folklores comprise the sum total of traditionally derived and orally or imitatively transmitted literature, material culture, and custom of subcultures within predominantly literate

..." However, it is not easy to define and to decide the origin of folklore as there are a number bibliography in it. Yet, it is still possible to use them as the sources of 
virtues to be taught to students. It is because folklore is the the reflection of human civilization that still have a relevancy to the today life.

Folklore is a part of narrative text. It is the traditional stories and culture of a group of people. As a local genius manifestation, folklore can be exploited to teach moral values to the language learners. It is due to the fact that there are a number of moral values kept withim the stories.

There are a number of folklores that can be brought into English language teaching. Roro Jonggrang, Asal-Usul Sungai Gajah Wong, and Asal-Usul Gunung Merapi are the examples of folklore that have a close connection to student's life. However, it is impossible to find the author names of folklore because they are anonymous. Even, it is because folklores were only transmitted from one generation to another (Danandjaja, 2014) via Kaltsum \& Utami (2016: 24). Furthermore, as an oral tradition, it is often to find linguistically complicated within the folklore. Therefore, tutors need carefully to adjust and modify based on the students' competences.

With the help of folklore, at least teaching narrative will find the following points; (a) students experience learning narrative is easy. It is due to the fact that the stories read by them are familiar enough, (b) students find that the text read by them is interesting since they are filled with a number of pictures, (c) the text is ease to be memorized because each paragraph is given a different colour, and (d) students can learn a number of moral values served by the actors from the stories. It's due to the fact that folklore contained wide range of moral value that can be used to reinforcement moral values as well as building students' self concept.

There are some points considered by the tutor when composing the folklore to integrate the moral values. First, the level of difficulty for vocabulary applied in the text. The tutor chooses the vocabularies that are familiar and often used in learning activities so that students easily understand the whole of the story. Second, the choice of folklore developed. Not all of the folklores can be used to teach English in the class. They must be selected based on some considerations and thereupon be developed by the tutor. Generally speaking, the folklore that can be brought in the classroom is that the one that have deep moral values and local wisdom. Even, the values that is certainly appropriate to the basic competence of the English language learning.

\subsection{The Happy Strategy}

A happy strategy is the strategy aiming to create joyful learning experiences. For learning is defined as a process to get knowledge, attitude, and value through sequences of instructions and experiences to support students' intelligence development (Washburne, 1936) as cited by (Wei, Hung, \& Lee, 2011: 11), then it is importatnt to provide a wide range of activities to transform the expected skills and virtues to the students. In other words, with the happy strategy, students will find that learning English is fun and amazing.

It is called happy because there are a number of activities supporting students to practice speaking English with free and ease. What is more, the happy strategy in this context is applied to strengthen the speaking skill particularly for narrative in the form of spoken text. With regard to harmonizing between the students' talent and some interesting activities, the happy strategy arrives to cover students' feeling to feel satisfy and pleasure so they will stimulate students to have a positive perception on the English learning process.

In a general stance, the happy strategy aims to harmonize the ability of the students with various activities. Therefore, the activities designed within consist of 
story telling, role playing, self assessment, peer assessment, and selected report. The following paragraph theoritically explained each of the activities.

a. Story Telling

Storytelling is the original form of teaching. It has the potential to foster the emotional intelligence and can help students to gain insight into human behavior. Even it also promotes language learning by enriching learners' vocabulary and acquiring new language structures.

With the story telling, students can retell the folklore they have read. It is because the activity of understanding the text can help them enable to remember the contents of the stories they have read. Furthermore, after they understand the contents of the story, they will also get some stimulations and positive sides when performing the story. It is in line to the argument of Ebrahiminejad, Azizifar, Gowhary, \& Jamalinesari (2014: 43) that short story is such a multi-dimensional literary that genre can be profitably utilized in the acquiring different language skills.

Storytelling in the happy strategy is done in groups. The arrangement of the group is randomly built consisting of students who are clever, moderate, and less. Stories are presented alternately in groups. Students can choose to share places such as in the playground, the school halls, parks, and in any places where they like. The tutor monitored the group while observing the learning process by using observation sheet. After they told the story in their group, the best students finally would be found and then asked them to show the story in front of class.

1. Role Playing

Role playing in the happy stratgey was defined as the activities that had a goal to train and build students' self concept through speaking activities. In role playing activities, students practiced to perform how the character in the story speaks or express their ideas. However the main objective of the role play activity was support students to speak English without embarrassed and oppressed. Therefore, bringing role play in the class was expected to make students feel entertaint. That is to say, with role play students can build their own communication. It is in line to the Ebong's argument (2004:1) as cited by Fabusuyi (2014: 246) that role-playing can become an indigenous technique of communication and it will help students to acquire a language even for entertainment.

\section{Self Assessment}

According to Andrade and Du (2007: 160) as cited by (Spiller, 2012: 3) selfassessment is defined as a process of assessing, evaluating the quality of work and learning. Then they are judged of their degree to which they reflect explicitly of the goals, identify strengths, and weaknesses in their work. Furthermore, Spiller emphasized that with self assessment one can make his/her self judgment about the progress such as by; (1) building a natural tendency to check out the progress of their own learning, (2) recognizing of what needs to be learned, (3) giving motivation for further learning, (4) encouraging reflection on own learning, (5) promoting to have self responsibility and independent, (6) encouraging student ownership of the learning, (7) focusing from something imposed by someone else to a potential partnership, (8) emphasizing the formative aspects of assessment, (9) encouraging a focus on process, (10) accommodating diversity of readiness, experience, and backgrounds, and (11) practicing align well with the shift in the higher education literature from a focus on teacher performance to an emphasis on student learning. 
Along with the goal of learning outcomes, self assessment is implemented in the process of speaking practice however it is without grading. Thereby, it is in line to the explanation expressed by Spiller (2012: 7) that self-assessment can enhance learning effectively as long as it does not involve grading. Furthermore, Boud (1995: 182) via Spiller convinced that self-assessment can be implemented with some considerations:

First, a clear rationale: what are the purposes of the particular activity, second, explicit procedures-students need to know what is expected of them, third, reassurance of a safe environment in which they can be honest about their own performance without the fear that they will expose information which can be used against them, and fourth, Confidence that other students will do likewise, and that cheating or collusion will be detected and discouraged.

That is to say, self assessment is a self-involved review process with the aim of helping students enable to monitor theirself. As a result, it is very helpful to apply in the speaking activities. With self assessment, students can take their position to build their own concentration in evaluating and improving her/him self.

3. Peer Assessment

Peer Assessment is also implemented in the sequences of the happy strategy. It involves "students providing feedback to other students on the quality of their work" (Spiller, 2012: 10). According to Falchikov (2007: 132) in the same manner as cited by Spiller that in peer assessment, it will support students to provide either feedback or grades to their peers on a product or a performance, based on the criteria of excellence for that product or event which students may have been involved in determining.

According to Kvale (2006) as cited by Spiller (2012: 11) "cognitive apprenticeship model" can also be formed when students doing peer learning. It is because peer assessment enables students to support them helping each other to make sense of the gaps in their learning and understanding as well as to get a more sophisticated grasp of the learning process.

Peer assessment in happy strategy is implemented to control students' behavior during the process of showing the story telling and role playing. As an addition, since in speaking activities students needs a free and relax situation thus students will be much calmer when they know that they are not observed formally by the tutor yet only by their friends.

Put more simply, in order to make students enable to build a positive self concept, and then they are trained to evaluate their friend's performance. Having done peer assessment, then it continued to find and announce the selected performer or the best of the best. The purpose of this last activity is to give appreciation to the students who have tried maximally thus finally they will find that learning English especially for speaking skill is very exciting.

4. Selected Report

Selected Report refers to the activities to find out the best performer from the speaking activities. The activities are done in a small group of four. It is believed that when students work in the group they can reduce their feeling of ashamed. Moreover, the implication of working in a small group is supporting students to feel relax. Indeed, students will automatically and naturally build their confidence. As an addition, the happy strategy supports students practice speaking English by choosing the story they like and the activity they think they can do with it. The end of the activities is finding the best performer who is able to inspire another student to practice speaking English therefore; this is called as selected report. 


\section{METHODS}

Substantively, this paper was based on the best practice done by the author several months ago. It was between Augusts until November of 2016. The subject of the best practice was students in the centre of society learning activities Tamanan Banguntapan Bantul especially for packet B program for grade seven. The class consisted of 20 students. Most of them were boys; there were only 3 girls in that class. During the teaching and learning process in term of implementing folklore with the happy strategy, the author used test (essay test as the instrument), check list (to observe the students' behavior), and peer assessment instrument to be used by the students to observe and score their friends' performance during conducting the story. Those gained data then were analyzed to decide and to determine the students' improvement on speaking skill and self concept.

\section{FINDINGS AND DISCUSSION}

In general, the discussion of finding and discussion covers the three points; linguistic aspect, linguistic performance, and moral values. Systematically, the discussion is devided into three points explaining about; (1) the integration of moral values through folklore in narrative texts, (2) the implementation of thehappy strategy in the teaching speaking, and (3) the improvement of students' speaking skill and self concept.

1) The Integration of Moral Values through Folklore in Narrative Texts

Folklore is a kind of story delivered orally from generation to generation that is not known its author. Stories that were composed by the tutor in that activity were accordance with the story in a general but it used a simple language. The tutor integrated the values of local wisdom so that students could learn some model of being a good people from them. Some of the folklores that had been modified are as follows.

a) The Story of Roro Jonggrang

Roro Jonggrang is one of the folklore that is very famous especially for the people of Yogyakarta. As part of the Yogyakarta community, students must know the story. The consideration of choosing this folklore was due to the fact that when students knew the existence of the story it would increase their pride. Furthermore, students would also try to appreciate the entire artefacts associated with the story such as Prambanan temple and Boko temple where the story took place. Both of those temples were the main setting of the story so that students could learn two elements (intrinsic and extrinsic).

Two elements contained in the story could be directly learned by the students. First, it was the intrinsic elements that include the characterization of the characters in the story. It could automatically inspire the students in term of noticing how the problems were handled by the main character. Second, the extrinsic elements showed the real existence of the setting in the story in which it automatically would make students feel curious and then bring their imagination to the locations that appeared in the story.

In general, through the story of Roro Jonggrang the students could learn some values of local wisdom such as (1) never boasting to anyone, (2) use a critical thinking, (3) always be careful and do not rush in running all the activities in our lives, (4) do not be easily fall in despair, and (5) able to establish good communication with anyone else.

b) The Origin of Kali Gajah Wong 
The story entitled The Origin of Kali Gajah Wong also has some good moralities to be taught to the students. Those good moralities can be exploited to be the sources of virtues therefore the students can conceive and actualize those in their life. From that story, the tutor modified into a simple reading text so it will help students learn both the language aspects and moral values. The Origin of Kali Gajah Wong is filled with a wide range of moral values, students surely has some good models to learn. Some good values that can be learned from this story are; (1) man should always be vigilant in acting and (2) and never hesitate to ask before doing everything. As the setting of the story was in the nature that is river thus students can dig out a number of local wisdom from it. It is very good to be brought in the English classroom and chosen as well as redeveloped to easy and simple reading text. As an adition, some points that need to be consider is that oral messages conveyed through the characters in the story are integrated in the English learning activities so that the students can learn them directly.

c) The Origin of the Name of Mount Merapi

Folklore entitled The Origin of Mount Merapi has the value of local wisdom that can be taught to students. Folklore that has a forest environment background in Yogyakarta can be used as a medium of cultural preservation of local communities. In addition, through this story, the tutor can also provide knowledge about the chronology of the emergence of Mount Merapi from several perspectives.

The folklore that tells the conflict between humans and gods in this story is not entirely believable. However, there are some moral messages that can be extracted and taught to the students. The moral values of the story; (1) the human should not be stubborn, (2) should be open, and (3) willing to receive input to find the best solution.

2) The Implementation of theHappy Strategy in Teaching Speaking

The happy strategy is a kind of joyful and fun learning experiences especially

for speaking activities. A sense of happiness is achieved by harmonizing the ability of students according to a carefully plan. The planned learning activity included of four phases; (a) Classical Activities, (b) Actualization of Students' Ability, (c) Appreciation of Students' Ability, and (d) Strengthening Student's Self Concept. Each phase has its own purpose.

The following figure is the visualization of thehappy strategy. The series of the core activities are storytelling, roleplaying, self assessment, peer assessment, and selected report in which the primary goal is to support students to speak English and build their self cencept. As an addition, after the students had performed speaking skill using folklores through the happy strategy, they did not only showing their academic achievement but also were able to have self learning, self correction, and conceived of their weakness and strength. 


\section{The Happy Strategy:}

Harmonizing student's ability with various joyful learning experiences

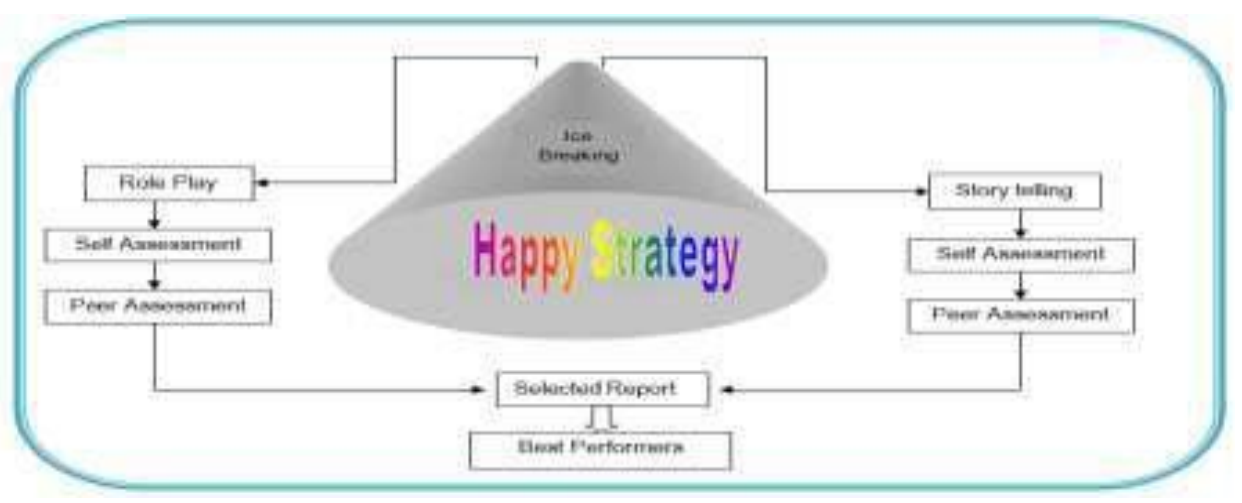

Picture 1. Happy Strategy

Table 1. Learning Activities with Happy Strategy

\begin{tabular}{|c|c|c|c|}
\hline Stages & Categories & Activities & Objectives \\
\hline \multirow{5}{*}{ Phase I } & \multirow{5}{*}{$\begin{array}{l}\text { Classical } \\
\text { Activities }\end{array}$} & 1. Ice breaking & 1. Practicing for pronunciation \\
\hline & & 2. Warm up & 2. Displaying excerpts of folklores \\
\hline & & 3. Pictures shows & 3. Displays pictures of folklore. \\
\hline & & 4. Building knowledge & $\begin{array}{l}\text { 4. Building learners' understanding of } \\
\text { narrative text. }\end{array}$ \\
\hline & & 5. $\quad$ Describing pictures & 5. Strengthen the vacabulary \\
\hline \multirow{5}{*}{ Phase II } & \multirow{5}{*}{$\begin{array}{l}\text { Actualization of } \\
\text { Students } \\
\text { Ability }\end{array}$} & 1. Story telling & $\begin{array}{l}\text { 1. Expressing meaning in narrative } \\
\text { text }\end{array}$ \\
\hline & & 2. Role playing & $\begin{array}{l}\text { 2. Expressing and actualizing in } \\
\text { sequences of actings the meaning in } \\
\text { narrative text }\end{array}$ \\
\hline & & 3. Peer-assessment & $\begin{array}{l}\text { 3. Training the students to appreciate } \\
\text { what friend' work. }\end{array}$ \\
\hline & & 4. Self-assessment & $\begin{array}{l}\text { 4. Building the awareness of the } \\
\text { students' self ability. }\end{array}$ \\
\hline & & 5. Selected report & $\begin{array}{l}\text { 5. Finding and determining the best } \\
\text { performer }\end{array}$ \\
\hline \multirow[b]{2}{*}{ Phase III } & \multirow{2}{*}{$\begin{array}{l}\text { Appreciation of } \\
\text { Students' } \\
\text { Ability } \\
\end{array}$} & $\begin{array}{l}\text { 1. Perform the best } \\
\text { practices }\end{array}$ & $\begin{array}{l}\text { 1. Providing some models to perform } \\
\text { storytelling and roleplay. }\end{array}$ \\
\hline & & 2. Appreciation & $\begin{array}{l}\text { 1) Offer inspiration (modeling) and } \\
\text { Providing testimonials }\end{array}$ \\
\hline \multirow{3}{*}{ Phase IV } & Strengthening & 1. Evaluation & 1. Evaluating of the entirely works \\
\hline & \multirow{2}{*}{$\begin{array}{c}\text { Student's Self } \\
\text { Concept }\end{array}$} & 2. Reflection & 2. Clarify students self concept \\
\hline & & 3. Reinforcemnet & 3. Wrapping up \\
\hline
\end{tabular}

In a general scope, learning activities with the happy strategy consist of some stages they are; (a) classical activities, (2) actualization of students' ability, (3) appreciation of students' ability, and (4) strengthening student's self concept. Each of the stage is explicitly explained below.

a) Classical Activities

Classical activity aims to build a fresh atmosphere. The lack of motivation to learn English and the low of self concept needed to be improved. In classical activities, fresh relevant and educational ice breakings were done. In this phase, students were gradually started to join the class activities. When doing ice breakings, the tutor repeatedly practiced pronounciation with a simply way 
through hand and body movement. Above all, the activity provided an opportunity for students to use vocabulary in a simple daily communication.

In ice breakings, the first pronunciation was begun with some simple words such as one, two, three, and so on. Furthermore, it was followed by some yells in the form of the sentences like "I am happy, you are happy, and we are happy" repeatedly again and again. Through the sequences of ice breakings, students begin to build a passion for practicing speaking English. Finally the tutor asked students to act one by one in front of the class while practicing and drilling some new vocabularies and sentences.

b) Actualization of Students' Ability

Actualization of students' ability aims to provide opportunities to the students in order to find out their potential such as doing story telling or role playing. Since speaking skill is a process of building meaning through the use of verbal symbols in various contexts, therefore, students are given the opportunity to practice performing the story. The types of activities in the actualizationphase include story telling, role playing, self assessment, and peer assessment.

c) Appreciation of Students' Ability

Appreciation of student's abilityaims to recognize or to understand his/her extraordinary in performing speaking through story telling or role playing. It is worth to do because in that phase, student's ability is exposed in a larger scope than in the previous one. As an addition, by giving admiration to the skilled students, it will support their motivation to do the best again and again.

Turning to the term used, the activity of giving an appreciation was called a selected report. It was called as the selected report because not all the students were given times to show their performace in front of the class but only a few. It was only the best storyteller and role player of each group who were given the opportunity to come and to show their story in front of their classmates.

d) Strengthening Student's Self Concept

Having done the sequences of speaking activities both in the small group and in the class, teacher strengthened student's self concept by asking them to discuss and to declare the moral values contained in the story that they had learnt. Strengthening the student's self concept was very crucial to do. It was because most of them had low self concept. Self concept is inculcated to the students by using the moral values obtained from the stories. Through discussing of some good values represented by the characters within the stories the students will directly learn and then start to think about him/her self. The students were also given time to do a reflection about the story they had read.

3) The Improvement of Students' Speaking Skill and Self Concept

Liao (2019: 12) said that at first, people have the notion that learning English

has something to do with oral English. It's due to the fact that people naturally think that one who learn English thus he/she must be able to speak or making interactional using that target language.

The English language learning using folklores through the happy strategy especially on speaking skill for non formal education can generally improve students' cognitive (linguistic competence), affective (self-concept), and psychomotor (ability to show verbal language skills). It is because students get ease to understand the content of the story. As an addition, besides speaking English becomes much easier, bringing folklores in the English language teaching also helped students to learn some moral values to improve their self concept. As folklores are part of local wisdom manifestations, there are a number of values that 
can be exploited to be used as the media to inculcate virtues. The students' improvement both for speaking skill and self concept are described below.

a) Linguistic Competence

Linguistic Competence refers to the students' understanding on language competence. It is particularly for narrative text including (1) purposes of the text, (2) generic structure of the text, (3) the language features mostly used in narrative text such as simple past tense, pronoun, conjunction, and so on. Using local stories in fact could improve and increase students'cognitive domain. The following chart shows how students can improve their understanding about narrative text. The average score increased from 58 to 70, while the highest and the lowest score also changed among the academic year 2015 and 2016.

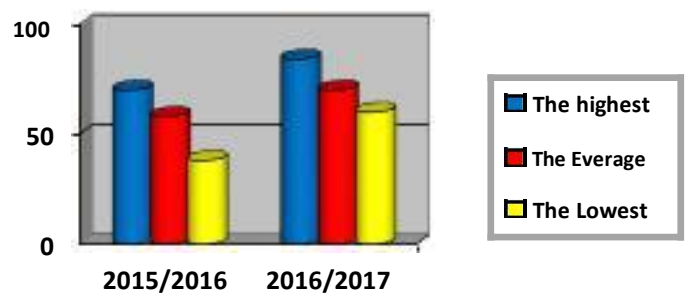

\section{Chart 1. Linguistic Competence on Narrative Text}

b) Linguistic Performance

The learning achievement in linguistic performance was shown from the students' ability in speaking English. Especially, it was the learner's ability in expressing the meaning of story. The following chart shows how students could improve their speaking skill about the narrative text. The average score covered four aspects; pronunciation, grammar, vocabulary, fluency, and understanding.

Linguistic performance or the ability to show the ideas in the form of spoken text could be shown from the following figure. As an addition, the highest score achieved by the students was the aspect of understanding for the content of the text and the number of vocabularies that they had gained. It was because the story that they had read was very familiar.
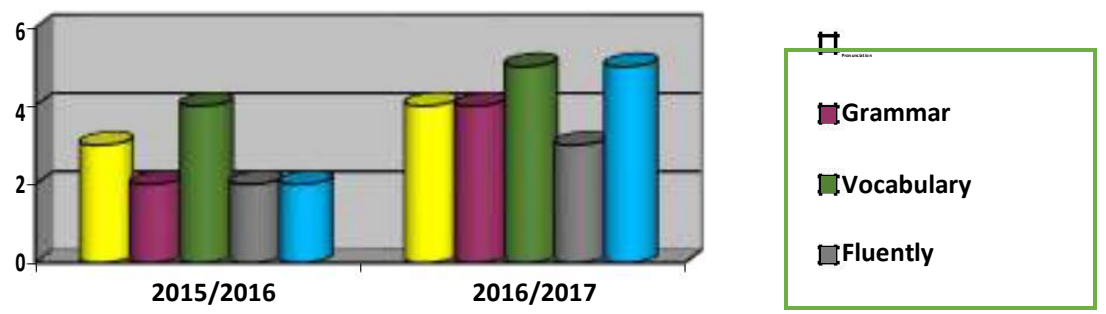

Chart 2. Linguistic Performance on Speaking Skill

c) Self Concept

Self concept in this context is the way students see themselves holistically covering physical, emotion, intellectual, sosial, and spiritual. While the dimension of self concept that was observed during the teaching and learning process particularly when implementing folklores and the happy strategy covered the following aspects both for internal and eksternal dimensions. The internal dimension consists of three aspects they are (1) self identity refering to 
student's perception on him/herself, (2) judging self, and (3) behavioral self while eksternal dimension consists of (1) physical self, (2) moral-ethical self, (3)personal self, (4) family self, and (5) social self.

Having distributed the self concept instrument to the students, the gained data showed that the students had positive self concept. As an addition, the results of observation about the changes of students' self-concept were very good. Inculcating virtues through some moral message appearing in the folklores was quite helpful for students in shaping their perception about their self. After understanding the character and characterization of the story, students can change their sefl concept such as; having a positive perception of their own life, optimistits in facing their future, never fall in despair when facing a little bit problem, and belief about their self quality.

\section{CONCLUSION}

Implementing folklores and the happy strategy in English classroom for non formal education to strengthen the speaking skills and self concept is success even it was easy to apply. It did not need any complicated requirement. Students can achieve their improvement both for speaking and self concept. The number of benefits when using folklore and the happy strategy are: (1) students found that speaking skills with narrative text is easier than using other stories, (2) the classroom atmosphere was conducive and fun as it supports students actively speak, (3) speaking activities such as story telling and role playing supported students to practice speaking English without fear and ashamed, and (4) peer assessment, selfreflection, and selected report could totafilly support students to find their hidden potentials. Put more simply, having been implemented folklores, students can make any reflection on their self concept. Students' positive self concepts were gradually increased.

\section{REFERENCES}

Byrnes, J.P., \& Wasik, B. A. (2009). Language and Literacy Development What Educators Need to Know. New York: The Guilford Press.

Ebrahiminejad, S., Azizifar, A., Gowhary, H., \& Jamalinesari, A. (2014). Effect of Using Short Story on Speaking Improvement of Iranian PreIntermediate EFL Learners. International Journal of Language Learning and Applied Linguistics World (IJLLALW), 42-56.

Fabusuyi, A. A. (2014). Integrating Folktales in the Teaching of German-A Practical Approach. International Journal of Humanities and Social Science, 246-251.

Kaltsum, H. U., \& Utami, R. D. (2016). The Effectiveness of Folklore Media Against Students' Motivation in Learning English. The Asian EFL Journal Second Language Acquisition - Academic Research, 20-36.

Liao, G. (vol.2 no.3 september 2019). Improvement of Speaking Ability through Interrelated Skills . English Language Teaching Journal, 11-14.

Nation, I. S., \& Newton, J. (2009). Teaching ESL/EFL Listening and Speaking. New York,: Routledge.

Spiller, D. (2012). Assessment Matters: Self-Assessment and Peer Assessment: Teaching Development. Waikato: Teaching Development. The University of Waikato. 
Wei, C.-W., Hung, I.-C., \& Lee, L. (2011). A Joyful Classroom Learning System With Robot Learning Companion For Children to Learn Mathematics Multiplication. The Turkish Online Journal of Educational Technology, 11-23.

Widiati, U., \& Cahyono, B. Y. (2006). The Teaching of Efl Speaking In The Indonesian Context:The State of the Art. Bahasa Dan Seni, Tahun 34, Nomor 2, Agustus, 269-292.

Woolfolk, A. (2007). Educational Psychology. 10 Edition. Boston: Pearson Education, Inc. 